\section{An international conference of the tobacco industry and its allies: one delegate's minority report}

\begin{abstract}
Alan Blum
Held every 3 years since 1983, the Tobacco International Exhibition and Conference serves to unite all aspects of the tobacco industry. At the fourth such meeting, held at Raleigh, North Carolina on 1-4 fune 1992, with over 120 booths in the exhibition hall and a packed room during the conference, the tobacco industry flaunted its powerful stature.

All the big names in the international industry either exhibited or were present - Focke $\mathcal{E}$ Company (cigarette packing machines), MacTavish Machine Manufacturing (tobacco leaf processing equipment), Hercules Inc (packaging films), Kimberly-Clark, and Philip Morris, to name a few. The exhibition hall was swarming with visitors and many contacts were made-both international and national.

ALYSON R BOXMAN, Tobacco International, 1 August 1992
\end{abstract} had been recognised and thrown out of the conference after the first day's lectures. "Really, Dr Blum, what are you doing here?" snarled a sour young man in a business suit, who approached me as we filed out of the session. "I don't know what you're trying to do, but you're not welcome here and that will soon be made clear to you."

It soon was. Barely four hours after sitting in, unobtrusively I thought, on the session "Leaf tobacco to the year 2000," I was being asked to leave town by Farrell Delman, director of the Tobacco Merchants Association, co-sponsor of the conference. Delman informed me that I was not permitted to attend the meeting, which was reserved for members of the tobacco industry. When I informed him that I had attended the group's previous exhibition (Appendix I) and that there had been no mention of such restrictions in any of the promotional literature I had received inviting me to attend the conference, he suggested that I may have deceived Tobacco International, which had handled the advance publicity and enrolment. None the less, he offered to refund my $\$ 600$ registration fee in full, along with all expenses I had incurred in travelling to the meeting (nearly $\$ 1000$ ). $\mathrm{He}$ also told me that he had discussed my expulsion from the conference with John Rupp, an attorney with the Washington, DC, law firm of Covington and Burling, who would accept my telephone call and would answer any questions I might have.

I pleaded as a journalist to be allowed to remain and explained, in all seriousness, that in order to write the most accurate analysis
That's not exactly how I saw it. Then again, I (and to prevent tobacco industry members' complaints of misrepresentation), it behoved me to be present at the conference. Delman was unmoved. Nor did he agree to my offer to be available to answer questions from conference attendees about the anti-smoking movement, although he said he would "discuss it" with others. Delman did not make me turn in my prized delegate's badge, which I had been issued the night before when I arrived to attend the opening ceremonies and cocktail reception (figure 1 ).

The theme of the conference was "Tobacco to the year 2000." According to Tobacco International, "The purpose is to make product manufacturers and leaf processors more aware of trends that will affect the tobacco business so that everyone can be prepared to react in a positive manner."

The first social event of the conference, held in a ballroom of the Radisson Hotel, was a lavish cocktail party hosted by Kimberly-Clark Corporation (Appendix II). A 30-piece uniformed 101st Airborne Division Band from nearby Fort Bragg performed a medley of deafening marches. During a break I asked the bandleader whether the band also played at weddings and bar mitzvahs. He wasn't sure how to take the question, but did say that it didn't cost the tobacco conference anything. Unless I misunderstood, all that an everyday taxpayer apparently has to do to get the band to play is to submit a request to the information officer at Fort Bragg.

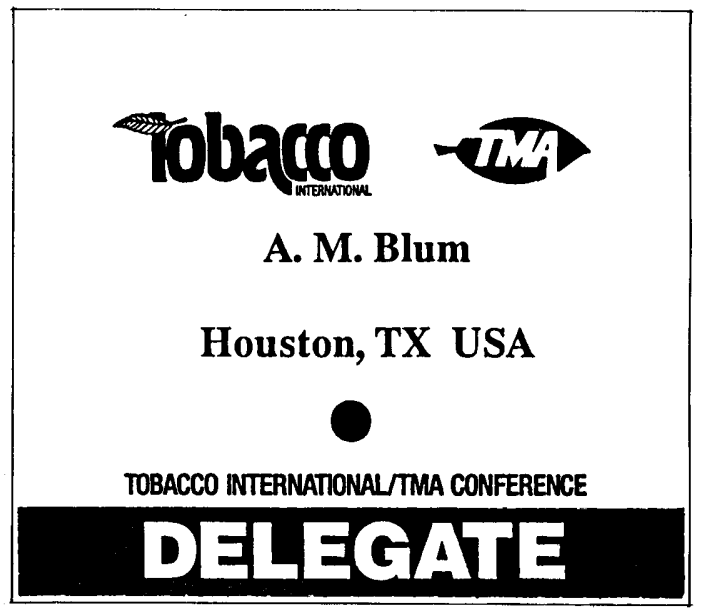

Figure 1 Prized delegate's badge 
The opening ceremony was even sillier than at most conferences. As a well dressed crowd of 250 people, nearly all men, stood wolfing down great quantities of shrimp, cheeses, fruit, meats, and pastry from an enormous buffet, the publishers of Tobacco International, George and Robert Lockwood, welcomed the attendees from over 70 countries (the number would be knocked down to 34 by the opening speaker the next morning). Highlights of the meeting, it was said, would be broadcast over 400 television stations and 200 radio stations around the world. Twenty-five women in red dresses then marched into the room, each carrying a different flag. One of the Lockwoods announced that this was the parade of flags of the different nations. Within five minutes the attendees were back to gorging themselves and lining up at two open bars. My only other conversation at the event was with a representative from the Ontario Flue-Cured Tobacco Growers Marketing Board. This person was not optimistic about the future of tobacco growing in Canada, noting that Koreans and other Asian immigrants had bought a number of tobacco farms and were now growing Oriental vegetables and Shatike mushrooms. On the other hand, the representative was not concerned about the Social Democrat government in Ontario, believing that even this leftist clique would continue to support tobacco growers as it tackled a large budget deficit.

\section{Flue-cured tobacco's bright future}

The following morning in the same ballroom seven male speakers lined the dais at the start of the first conference session; 85 people, including seven women, were in the audience. The chairman of the session was WK Collins, $\mathrm{PhD}$, author of the textbook Principles of FlueCured Tobacco and holder of the Philip Morris Professorship at North Carolina State University. None of the speakers was more earnest than O Witcher Dudley III, vice president for leaf tobacco at Philip Morris, who remarked that "next to cigarettes, the anti-tobacco movement ranks as one of America's most successful exports." Dudley concluded his comments as follows :

My company, Philip Morris, believes the worldwide cigarette market [will] grow and is backing that belief with $\$ 3$ billion worth of plant expansions, modernisations, and other capital improvements between now and 1996 in the US and Western and Eastern Europe.

Business is going to be good for the remainder of the century, but it's not going to be the same business it was 10 years, five years, or even three years ago...

We will have to hunker down to fight the antitobacco movement for at least the rest of the decade.

And we will have to accept the fact that every segment of the tobacco industry has to make a joint commitment to fight to manufacture our products freely and profitably.

In the session on the supply of and demand for tobacco, I learned that the future for fluecured varieties is extremely bright. The slight decline in United States consumption is more than being made up for in world demand. As a case in point, in less than 15 years since the introduction of so-called blond flue-cured tobacco in Spain, the country is successfully shifting away from its century-old tradition of dark, fermented tobacco. In contrast, in Greece, the continued emphasis on the growing of strong Oriental tobacco seems to have left that country struggling for market share. A speaker from the United States Department of Agriculture addressed the session on the subject of the GATT agreements, which deal with trade and tariff agreements in the global economy. He noted that the United States stands to benefit tremendously because of the growing demand for American blend cigarettes and leaf tobacco. Moreover, the general consensus of the session was that the United States price support programme is one subsidy that hardly qualifies as a true subsidy, compared with other countries, since its net cost is negligible. Another speaker from a leaf trading firm added that tobacco producers and manufacturers actually subsidise the federal government with more than $\$ 11$ billion a year in a tobacco marketing assessment.

Although excluded from the conference, I determined to make a thorough exploration of the exhibition. I met a charming fellow from a British chemical company, who invited me to visit him and his family on my next visit to the United Kingdom. He, like many other exhibitors, did not come from a tobacco background. Their corporations were there to show support for the industry, even though many did only a miniscule business in tobacco. But ferreting out such relationships (or whether a supplier might also be involved in healthrelated activities such as pharmaceuticals) became my focus during attendance at the exhibition. In visiting the exhibition for several hours over two days, I asked questions of individuals at 69 of the 109 exhibit booths and was aware of the nature of another nine but did not visit them or 31 others.

\section{Healthful allies}

A few of the corporations at the tobacco exhibition seem to have ties at least as strong to healthier industries. (In fact, three companies - Sandoz, Kodak, and Kimberly-Clark are also major exhibitors at medical conferences such as the American Academy of Family Physicians.) Sandoz was represented at one booth by its subsidiary Zoecon Corp, Dallas, Texas, named after the company's hormonal pesticide - or insect growth regulator in the trade. Another Sandoz-related company was Northrup King, a Minneapolis firm that develops and markets tobacco seeds. Siegling America, of Englewood, New Jersey, a world leader in synthetic conveyor belting for processing tobacco leaf and manufacturing cigarettes, also makes treadmill belts for cardiovascular stress testing. Proctor and Schwartz of Horsham, Pennsylvania, a global corporation that manufactures tobacco dryers and processing equipment, also makes machinery 


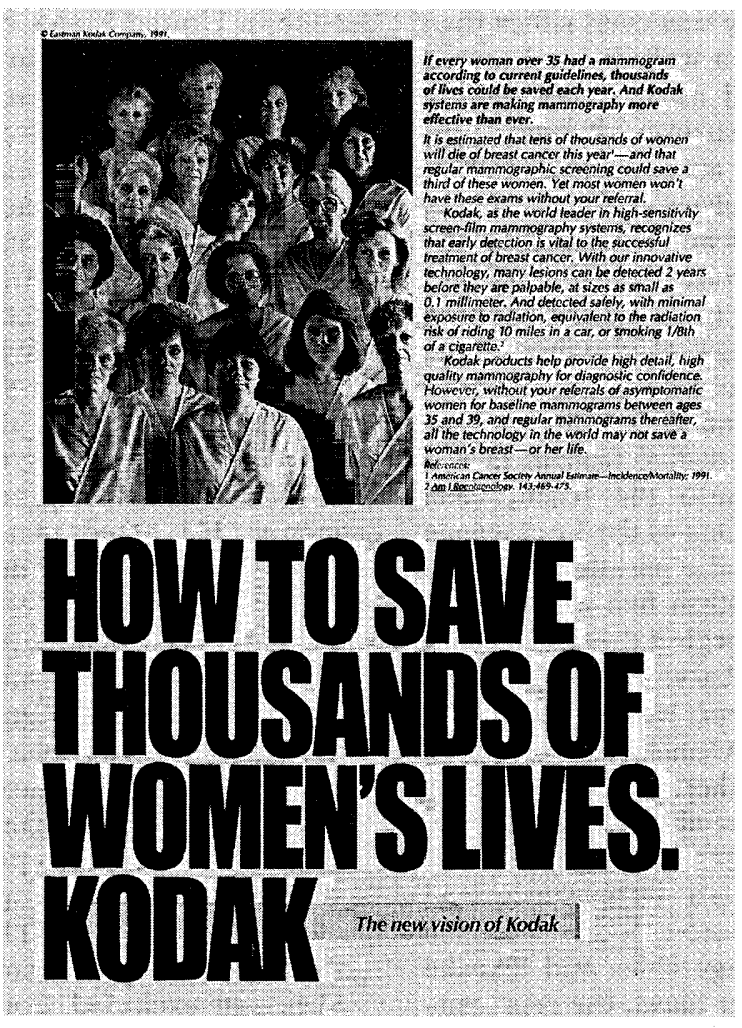

Figure 2 Advertisement for Kodak mammography systems from Postgraduate Medicine, 15 September 1992

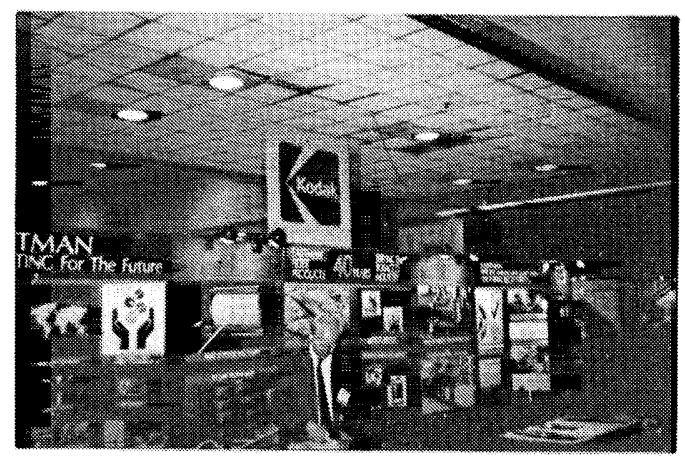

Figure 3 Kodak exhibit at fourth international exhibition, Raleigh, North Carolina, 1-4 June 1992. The exhibit featured the company's cellulose acetate material, supplied to the tobacco industry around the world, as well as the company's visual monitoring system to check for imperfections in cigarette packaging

for the pharmaceutical industry to produce granulated medications. Eastman Kodak's Videk Systems Division makes visual inspection systems for cigarette packaging, as well as for pharmaceutical packaging; another Kodak affiliated company, Eastman Chemical Products, Inc, Kingsport, Tennessee, in 1992 celebrated the 40th anniversary of its development of cellulose acetate cigarette filter material (figures 2 and 3). Kimberly-Clark, Roswell, Georgia, the maker of Kleenex tissue, Kotex sanitary towels and tampons, Huggies disposable diapers (nappies), protective surgical masks, gowns, and hospital supplies, splits the US cigarette paper market with Ecusta, a North Carolina subsidiary of a German company, Julius Glatz (figure 4).

In a presentation on the second day of the conference (an outline of which I subsequently obtained), Kimberly-Clark representative Alain Charet spoke of the increasingly close teamwork between tobacco manufacturers and suppliers of filters, flavours, and cigarette papers in the development of new cigarettes. This is his description of what he calls the "year 2000 cigarette":

The cigarette will probably be below $12 \mathrm{mg}$ tar, biodegradable, made [on machines that run] at 15000 cigarettes per minute, using white, opaque, heavily marked cigarette paper which will be delivered just on time by a company having a good environmental policy.

According to Charet, cigarette paper is made from "bleached pulp [of wood and flax fibres], calcium, carbonate, and burn additives." To Kimberly-Clark the ever-tightening regulations on the disposal of pulp and other chemical wastes pose a greater threat to cigarette paper makers than the anti-smoking movement (Appendix III).

As environmental issues become more critical, the company is touting a new "ultravioletdegradable" cigarette filter called Dimension, which it claims may replace cellulose acetate as the major material in future brands. In creating this polypropylene filter, Kimberly-Clark "adapted a modern technology used in many of its most successful consumer products to the need of the tobacco industry."

According to World Tobacco $(1992 ; 127$ : 68 ), the company also recently received Canadian patent number 2024367 for a cigarette paper that provides substantial reduction in sidestream smoke without adverse effects on mainstream particulate and puff count. Key to the patent is the use of burnmodifying chemical additives such as monoammonium sulphate.

Finding the proper chemical burn additive is another crucial issue for cigarette paper

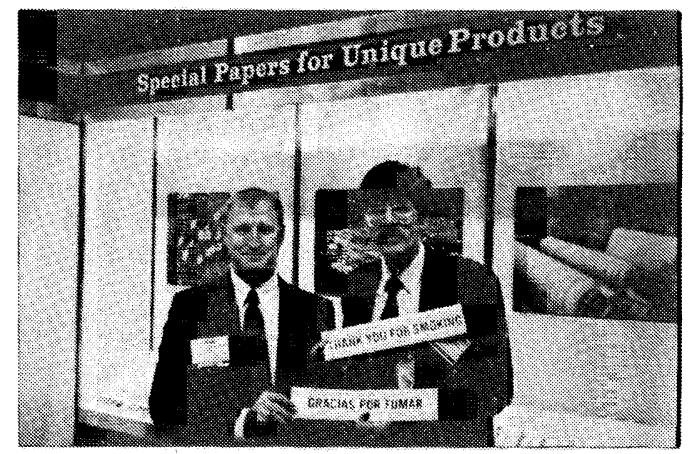

Figure 4 Dr Alan Blum (right) with a sales representative from the Ecusta division of the German firm fulius Glatz. The two are holding up examples of the "Thank you for smoking" signs in more than a dozen languages that were given out at the company's exhibit booth. The salesman confided that one of the Asian language signs actually reads, "Please translate this sign." In addition to cigarette papers, Ecusta produces paper for Bibles and paper used for instructional insertions in drug containers. 
manufacturers as they portray themselves as sensitive to the concerns of both smokers and environmentalists. Charet explained that cigarette paper "regulates burn rate, puff count, ash appearance, smoke deliveries for mainstream and sidestream, and as a consequence of all these, taste."

The description of Kimberly-Clark at the conference as a manufacturer of "quality cigarette components for over 75 years" hardly jibes with the more familiar image of the company as a maker of health-related paper products. But indeed, this major sponsor (along with Philip Morris) of the Children's Miracle Network (a coalition of hospitals "dedicated to the health and wellbeing of children") is also the world's largest manufacturer of cigarette papers and reconstituted tobacco for use in cigars and cigarettes. The company's mills are located in the United States, France, Colombia, Mexico, the Philippines, and Indonesia.

A brochure entitled, "Kimberly-Clark: innovative products for the tobacco industry," which was distributed at the conference, notes that "with a commitment to research that's unsurpassed among tobacco industry suppliers we've positioned ourselves to remain your primary partner well into the 21 st century."

Kimberly-Clark's main rival, Julius Glatz, is described in Tobacco International as the environmentally friendly paper company. This presumably results from the fact that in 1990 Glatz became the first manufacturer to introduce cigarette paper made from pulp bleached without chlorine. The journal reports confidentially that Glatz is "in the drawing stage on a patent on cigarette paper for very low sidestream smoke in the ashtray. This means that no smoke gets released from the cigarette itself. The company is constructing the cigarette paper so it stops burning after a few seconds. This is a safety device which also cuts down on sidestream smoke (I wonder what the anti-smoking advocates will have to say about that?)."

\section{Research : designs on consumers}

One of the most intriguing abstracts in the exhibition souvenir catalogue described an unpublished consumer study that showed how cigarette brand preference could be reinforced by the colour of the protective lining of the inside of the cigarette pack, known as the innerliner. Gleam Metallic Papers, a German ink manufacturer, invented a process for making gold and silver coated paper innerliners - called Gleamalor TM - which it hopes will replace traditional aluminium foil innerliners. The company conducted the study with RJ Reynolds in 1986 in Germany. Eight hundred and forty smokers of popular brands were recruited. They were divided into seven groups of 120 , evenly matched for age and sex.

For the purposes of the study, the researchers created a new brand called " 19 ", which was derived from the fact that in Germany there are 19 cigarettes to the pack. The fictitious brand was manufactured with both an aluminium foil innerliner (similar in appearance to the wrapper on a stick of Wrigley chewing gum) as well as with three different new innerliner designs in silver and gold (for example, silver on a dark blue background, which the researchers called "negative blue and silver with logo," or solid silver with fine lines that gave it the appearance of fabric).

As Fred Schulz, the manufacturer's representative at the Gleamalor booth, explained to me, "We wanted to have absolutely normal cigarette packaging with a neutral name, and we told them it was a new brand. 'Compare it with your regular brand,' we said, 'and please tell us how you like the cigarette." "'

Subjects each received 10 packets each containing one of the four different innerliners, and at the end of two weeks were asked their opinion about the brand name, taste, aroma, and, most importantly, whether they would buy the brand. When grouped by buying intention, all of the Gleamalor design innerliners were preferred over the aluminium innerliner.

"You know what we find out?" the manufacturer's representative exclaimed. "That the people believe when the cigarette company's doing something that looks different, it must be better.

"After this study, RJ Reynolds bought our ink and made a similar study using several of their existing brands. They found it seemed to add value to the product. The image of their brands goes up with our innerliner. Reynolds has now changed all their brands in Europe to include paper innerliners."

I wondered about RJ Reynolds' heavily promoted new packaging called The Wrap that had been the major advertising theme in early 1992 for the Winston and Salem brands. I was fascinated by the representative's response.

"That's only domestic [United States]. They won't be able to produce that in Europe because it's not biodegradable. It's metallised film. The environmental pressures in Europe are far, far greater. Eighty per cent of all packaging material in Germany has to be collected and recycled. The German packaging laws say in the future you can use only one component in packaging. You can't laminate something to something else because it's not recyclable."

"So an inked paper innerliner hasn't been introduced in the United States?" I asked.

"That's why we're here. We think it will come soon. This is something everybody needs to know about."

\section{Appendices}

Appendix I: An earlier visit to a tobacco industry exposition

In 1989 I attended the Third Tobacco International Exhibition and Conference in Winston-Salem, North Carolina. I registered under my own name and for my affiliation I wrote "P Toohy," an orthographic pun on the sound cartoon characters make when spitting - "ptooie!!" I roamed freely in the convention centre, and whenever exhibitors inquired 
about $\mathrm{P}$ Toohy, I had to bite my tongue and explain that I was an analyst sent to learn as much as I could about the tobacco industry. "Oh, an analyst!" they'd respond excitedly, no doubt thinking I was some sort of influential investment guru. "Then you really ought to have a copy of our latest report" that they'd kept hidden and separate from their stack of hand-out literature for the ordinary passer-by. In a single day of visiting 70 exhibit booths, I came away with over $25 \mathrm{~kg}$ of such reports.

At the conference I slipped into the queue for a rare field trip to RJ Reynolds' Tobaccoville, the largest and most modern of all cigarette factories, which is closed to the public. In the lobby young women handed out expensive gift boxes full of its tobacco products as well as limitless quantities of miniature Baby Ruth candy bars, packs of LifeSavers, and other confectionery made by the company's Nabisco subsidiary. After viewing a short film documentary about space age cigarette making, the 25 or so in our group walked around the spotless and highly automated plant, with such marvels as driverless trains individually programmed to deliver enormous containers from one place to another at various stages of the manufacturing process. Walking past a room that the guide noted was barred to all visitors, I inquired what went on inside. "That's touchy," she said. "It's where they fluff the tobacco in the cigarette, and they still use fluorocarbons." So not only was the company sucking the oxygen from the lungs of its smoking customers, it was also helping to deplete the earth's ozone layer. On the bus ride back to town, my seatmate, a sales representative from the United Kingdom, railed against the "anti-smokers." Although he himself had long since stopped smoking, his theory was that if cigarettes were to die out then the people in the anti-smoking crowd would simply go after something else, like sweets or red meat. "They're just contrary people, that's all," he told me.

Reinforcing this belief was an address by a tobacco industry scientist who presented the results of an experiment measuring reactions to environmental tobacco smoke in various workplaces. He suggested the matter boiled down to psychological factors, not physiological or pathological ones. The speaker backed up his case with a concluding slide of a newspaper photograph showing a vocal antismoking activist in chef's garb presiding over a smoky barbecue at this group's annual picnic.

At the exhibition hall I was initiated into a fascinating world of corporate allies of the tobacco industry. The exhibitors included several manufacturers of plastic film cigarette pack wrappers such as Mobil and Hoechst (makers of Lasix and other medications); the world's largest cigarette paper company, Kimberly-Clark; an adhesives maker better known for its dairy products, Borden; the Tobacco Farm Life Museum in Kenly, North Carolina; various tobacco farming organisations such as the Ontario Flue-Cured Tobacco Growers group; and tobacco conglomerates Philip Morris and RJ Reynolds. The RJR display, largest of the exhibition, featured a jeep representing the company's Camel safari road rallies and a race car beside a television monitor playing a rock video that glorified the image of the Camel formula one racing team. RJR gave away photographs of visitors posing in front of the cars, and a hostess I talked with later posted me the rock video. I learned a lot and was never challenged.

Appendix II : Stockholder's proposal by the Evangelical Lutheran Church at the Kimberly-Clark Annual Meeting, 27

\section{April 1990}

Excerpts from the resolution

"WHEREAS, in the USA cigarette smoking kills more people than heroin, cocaine, alcohol, AIDS, fires, homicide, suicide, and automobile accidents combined... [and whereas] an estimated 2500000 tobacco-related deaths occur worldwide annually... [and whereas] the Director General of the World Health Organisation called for a 21 st century 'free of tobacco-related diseases'... [and whereas] our Company makes [numerous paper] products for the tobacco industry...

"RESOLVED, that... after December 31, 1999, the Corporation shall not conduct any business related to tobacco or tobacco products."

Excerpts from the Response of the Corporation "...As corporate citizens of the larger community, we should be and are mindful of the society's interests, but our specific objective is not the social common good. That is government's special responsibility. Rather, Kimberly-Clark's special objective is the particular good of those who depend on the Corporation's success, i.e. stockbrokers, employees, and, indirectly, the communities where we are located...

"The Corporation does not promote smoking, but it is neither competent nor obliged, nor should it be, to force individuals to stop if they have chosen to do so...

"There is, perhaps, an even more compelling reason to reject this Proposal. To discontinue our tobacco-related business would result in the loss of employment for approximately 2700 people throughout the world, the loss to the communities where the businesses are located of substantial economic benefits and the loss of profits to the stockholders. This appreciable harm would not be offset by any comparable benefit to any segment of society because alternative sources of supply of the products which KimberlyClark manufactures would remain readily available throughout the world...

"Management believes that to curtail this aspect of our business would do considerable harm. It would do no good. It would establish the precedent for making a decision on an irresponsible basis. The business judgment of directors and management cannot and should not be exercised in such a fashion...

"Management also believes that the judge- 
ment as to whether to ban the manufacture and sale of tobacco-related products should be reserved to the government."

Excerpts of statement by Alan Blum MD, at the request of the Evangelical Lutheran Church, Kimberly-Clark annual meeting, April 27, 1990

"To suggest that 2700 employees could possibly be put out of work by the ending of the Tobacco Products Division is an inappropriate argument. I would like to invite any member of the Board of Kimberly-Clark [on which there are two physicians and a priest] or any of its officers to come with me to hospitals to see people who are permanently put out of work by tobacco industry products. It is folly to believe that we could not also phase these employees into other areas of the corporation.

"As to the argument that there are other suppliers who will fill the void if KimberlyClark vacates or sells off its tobacco products sector, this is a cynical and pitiable response that is incompatible with a vision of a kinder, gentler nation...

"We will have no credibility when we talk of a war on drugs while we are part of a network helping to push this poison throughout the world. It speaks of a Marie Antoinette attitude: 'Let them eat smoke!'

“... The company's credibility, good name, and... financial stability [will be harmed], as consumers turn to products made by [rival] manufacturers with a greater commitment to health and well-being."

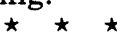

The resolution received $3.5 \%$ of shareholder votes, making it eligible to be brought up again at any time.

Products for the tobacco industry manufactured by Kimberly-Clark ${ }^{\star}$

- Cigarette paper

- Porowrap ${ }^{\circledR}$ porous plug wrap paper

- Conventional plug wrap paper

- Tipping base paper

- Dimension ${ }^{\mathrm{TM}}$ polypropylene cigarette filter material

- Reconstituted cigarette and cigar tobacco

- Reconstituted cigar wrapper and binder

* "A heritage of excellence: Kimberly-Clark Specialty Products... Quality products for the tobacco industry since 1908" [advertisement], Kimberly-Clark Corporation, Roswell, Georgia, in Tobacco International 1992; 194 (17): 47. (1 October.)

\section{Appendix III: Tobacco and environmental sensitivity}

The coincidental timing of the opening of the global ecology summit in Rio de Janeiro was not lost on the speakers or exhibitors. Indeed, environmental sensitivity was a recurring theme of the tobacco conference. Although the tobacco industry has not acknowledged that its products cause health problems to consumers, it appears to be quite concerned about risks of pesticides to farmers and the environment. The chain-smoking leaf director of a Brazilian tobacco company addressed the topic of controlling chemical residues left on tobacco leaves. He suggested that better biological rather than chemical agents could help solve the problem, as could crop rotation, and changes in the transplanting times of young tobacco plants. "Adoption of environmentfriendly practices should be encouraged," he concluded.

Such concerns were no doubt behind Sandoz's development of its Kabat tobacco protector (and Zoecon for protection of stored tobacco), touted as having the "lowest toxicity of any available tobacco insecticide" and eliminating "worker exposure to hazardous pesticides." An "Earth Day Honor Roll Award" certificate presented to the company in 1990 by an organisation called the National Environmental Development Association was prominently displayed at the exhibition.

One speaker from Zimbabwe, Don Lapham, did acknowledge that air-cured tobaccos are environmentally "easier" - namely, because they do not require the cutting down of trees for fuelling the flue-curing process! Lapham's solution was to accept the growing popularity of flue-cured tobacco, especially in underdeveloped countries, and to lessen environmental risks by choosing less erodible soils, improving drainage, and planting more tree lots designated specifically for wood to be used in flue-curing tobacco.

Thus, just as tobacco companies began responding half a century ago to growing health concerns about smoking-by widely advertising various filters and other gimmicks such as low tar cigarettes that could implicitly lessen the risk of disease - so they now actively seek to appear as guardians of the environment.

In Brazil tobacco growers have taken the issue a step farther-some might say to ridiculous lengths. "While ecologists all over the world are paying with pain and peril for their preservation efforts," writes correspondent Guido Jungbluth in the 15 July 1992 issue of Tobacco International (194 (12): 9-12), "the tobacco growers in South Brazil have willingly become the most eco-conscious farmers in the entire country." The growers' need to replenish their constant supply of trees for flue-curing tobacco has led them to campaign for reforestation. AFUBRA, the 37year-old tobacco growers association, has launched a preservation effort called "Life is Green", involving 58700 students in 1035 schools.

The symbol of the campaign is AFUBRINHA, "a friendly, lively mascot, half man and half tree, which returns with a smile each and every ecological effort." Tobacco growers hope the mascot will also be perceived as representing "the survival of the endangered human species". 